\title{
Photo art creativity in the education: Light drawing
}

\author{
Haci Mehmet Acar ${ }^{1 \mathrm{a}}$ and Tamer Kavuran ${ }^{2}$ \\ ${ }^{1}$ Mersin University Press \& Public Relations Department, 33343, Mersin, Turkey \\ ${ }^{2}$ Frrat University Faculty of Communication, Department of Visual Communication Design, 23119, \\ Elazı̆̆, Turkey
}

\begin{abstract}
Since the early ages, people live together with art, and create various branches of art. Painting, as one of the most important branches of art, occurs on the walls of the caves of prehistoric ages. By the nineteenth century, photography shows itself and come as a branch of art until today. Photographers have created new methods and techniques throughout history. Among these, we can say that "painting with light" is one of the techniques by which the artist can create original works of art and reflects his/her creativity freely. This study aims to cite the importance of creativity in art education by the applications of "painting with light". First the history of art is touched briefly, and then the invention of photography is mentioned and the relationships of photography and painting is studied. In the final section by informing about the technique of "painting with light", it is discoursed how to get a work of art with this technique.
\end{abstract}

Keywords: photograph; light drawing; art; creativity

\section{Introduction}

Since the early ages the humankind been intertwined with art and it has produced a variety of arts. The painting, which is the one of the most important art branch, has been arised by cave pictures. Paleolithic era people drew pictures on the walls of caves and bunkers. These pictures are the first examples of visual communication works and they have gained new dimensions by the result of social developments over time. The curiosity of imitating the images of nature has led to the invention of photography. The photography has a rapid development until today Niepce's first photograph. Photography today is an important addition to the arts and also emerges in every area of life as a result of technological progress. One of the important areas in the development of individual creativity in the education process is the education of art. In our day the visuality is more important and at the same time the photo art which is the one of visual communication tool in highlighting

${ }^{\text {a }}$ Corresponding author: mehmetacar@mersin.edu.tr

(C) The Authors, published by EDP Sciences. This is an open access article distributed under the terms of the Creative Commons Attribution License 4.0 (http://creativecommons.org/licenses/by/4.0/). 
the creativity has emerged with various techniques. One of them is the light painting. In this study it's aimed to explicate and remark the degrees of the light painting. It is also aimed to explain what is the importance of the development of the technique of light painting effect on a person's creativity and creativity by using the examples of the light painting technique.

\section{Creativity in art education}

Creativity is a phenomenon, which is a part of human nature, and it is possible to define the concept of creativity in many different ways. In common, creativity is "making and developing connections among ideas and contexts that are far from each other in meaning, actualize multifaceted perspectives, a dense curiosity, flexibility in thinking and actions, producing various and advanced solutions to problems qualitatively and using common objects in unusual ways" [2]. It may also been considered as "designing something that does not exist before, thinking different from anybody else and ability of producing new ideas upon different ideas." Creativity is universal and may appear different in every other people. The education of art aims developing the ability of creativity or the develop the skills on expressing emotions, ideas, impressions of an individual or a student. More than training an artist, the education of art targets a development in creativity and leading the students to creative thinking. "Dealing with art, no matter the level of interaction, does not only develops the sense of taste and aesthetic sensibility but also keeps alive all the intellectual processes in all cognitive dimensions" [2].

\section{A short history of photograph}

According to Benjamin [1] the curtains of fog over the first period of photography is not dense as the first periods of print works. From the very beginning of the history, humanbeings have always been interested in carrying the events of nature, objects and their interactions over a surface. Whether consciously or unconsciously, people tried to understand the new conditions by observing the changes in nature.

"The word photograph first used by Sir John F. W. Herscel in 1840. The word photograph is a combination of Greek words "Photos" (light) and "Graphies" (Lines) and in a way it means, "drawing with light" [3].

Passing an image over a surface "literally as a photograph" had became real by the studies of many people, mainly Joseph Nicephore, and Lois Jacques, Mande Daguerre, William Henry Fox Talbot. In 1816, J. N. Niepce used silver chloride as a "sensetive to the light material" in his experiments and tried to acquire image. But after a decade, in 1826, he obtained the first image. Another important researcher working on forming photographs is Jacques Mande Daguerre. In 1837 Daguerre began to make a progress and reduced photograph developing time from 7-8 hours to below 1-2 hours. Both the chemical processes used in photography and the cameras have developed rapidly and became an instrument of visual communication and art, used almost in every aspect of life.

\section{The light painting technique in photography}

The first sentence heard by the people who met the photography is "no photo without light". If the light which is essential part of the formation process of the photo, control by the photographer, original work of art will be come in sight. The light painting, a very simple sense, is lightening the object to be photographed or space that is responsive to the sensor layer, it is lit up like a paint brush. Therefore, the light required to correct the sensor 
is exposed, the entire surface is uniformly transferred to the material at hand. The resulting aesthetic appearance diameter of the light source may vary depending on the residence time in the light of the object and the object 's surface form.

\subsection{Materials required for light painting photography}

Having a professional equipment to achieve the desired results using the light- painting technique will provide better pictures to come out of. Therefore, a broad list of materials may be needed. A SLR camera that can shoot in bulb mode, will provide an appropriate setting for the purpose lenses, cable or remote shutter trigger, robust and high quality tripod, a variety of light sources, a dark environment and that the person or persons who may work together is crucial.

\subsection{Shooting and exposure}

One of the most important stages of the drafting stage is fixing the camera. Therefore it is important to use a stable tripod. The composition must be created before the shooting to determine the appropriate lens and viewfinder. Sharpness setting must be set manually. Otherwise, the camera will not clear in the dark. Appropriate iris diaphragm must be determined for finding ideal light of the shooting stage. Therefore it accomplished a few test shots. The shutter speed should be on "bulb" mode. Finally it should be checked from the viewfinder area for drawing. With the extinguishing of the light by pressing the shutter button starts shooting. A drawing or painting is performed by any light source. At this stage, the resulting image is dependent on the photographer's creativity. If you need the frame to enter the person who will perform the painting must wear dark clothes.

\section{Case studies}

In this part of the research there are light painting pictures created by various techniques.
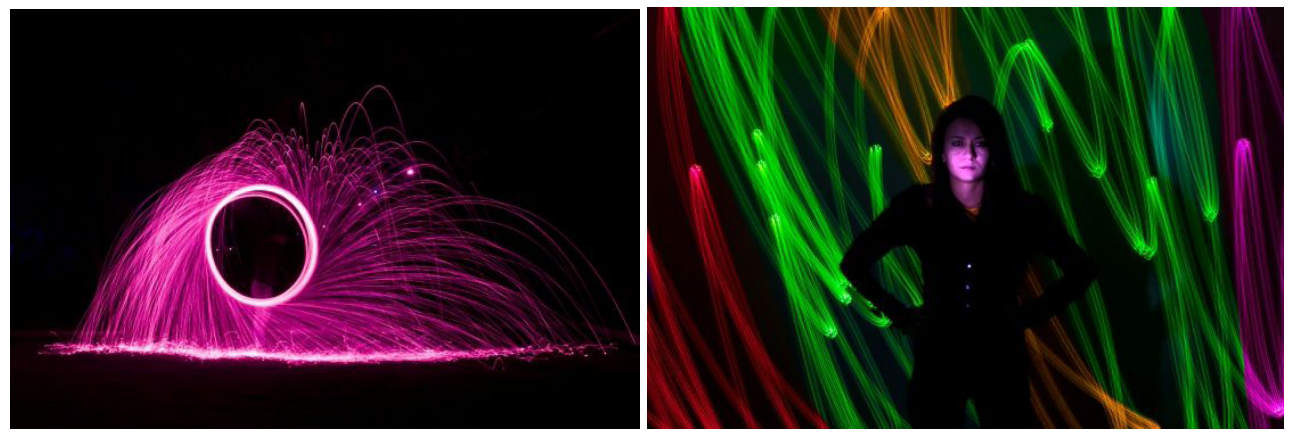

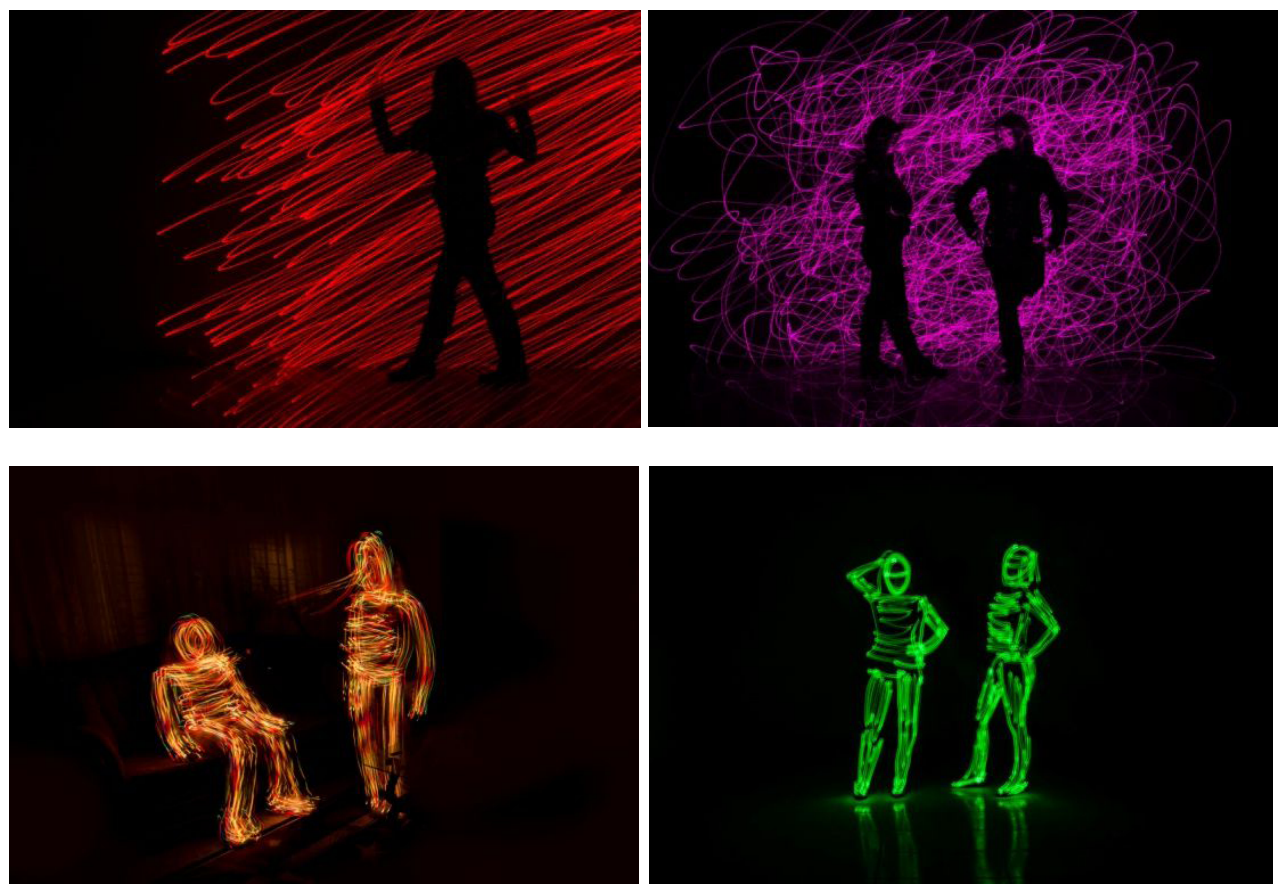

\section{Results}

The painting has affected people ant communities in every time zone throughout history. Painters express their thoughts and emotions with line, movement, colors and materials with a variety of paper, cloth, wall, stone, wood, etc. A painter uses a variety of materials while performing. These materials are mostly paint, brushes, pencil, coal and any material that could be used by artists. Tools to be used for painting by the artist show change in line with his purpose and which is to be used is limited by his imagination and creativity. From the cave paintings to the pictures that under the influence of religion in the Middle Ages, from the human -centered approach which is created by the renaissance to the modern art movements the artists processes of painting has emerged with different stylistic elements.

The painting has been shown with different formats and different presentation. It has also been expression of artists. In the structure of the image, which is an expression means, it must not ignore the existence of philosophical views that reflect the artist's expression in the picture. Photography also reflects the creative efforts of the artist as the other arts. The light is the most important material of the photographer. The most basic photo info is there's no photo without light. Photography is a very important part in the art world since it's invention. Reflection of the images in the nature like a mirror is the photography's real feature.

But photography is also influenced by the style and flow out over time as the other arts. In this study, it's been tried to produce photos with light painting technique by the relationship painting and photographic art. The pre- edited images are found on digital sensors in a dark environment. It seems like painting on digital sensors by using light. In this study it's also been stated that the technique of light painting can be develop creativity. 


\section{References}

1. Benjamin W. Fotoğrafın Kısa Tarihi, Agora Kitaplığı, İstanbul, 3, 6, (2013).

2. Cevizci A. Eğitim Sözlüğü, Say Yayınları, İstanbul, 505, 453, (2010).

3. Kanburoğlu Ö. Haber Fotoğrafçılığı, Say Yayınları, İstanbul, 30, (2013). 